early testing for stem growth in coastal Douglas-fir. Silvae Genet. 50: 167-175.

AdAMs, W. T. and D. G. Joyce (1990): Comparison of selection methods for improving volume growth in young coastal Douglas-fir. Silvae Genet. 39: 219-226.

BRuce, D. and D. J. Demars (1974): Volume equations for second-growth Douglas-fir. USDA, Forest Service Research Note PNW-239, USDA, PNWFRES: Portland, Oregon.

CAMPBELL, R. K. (1986): Mapped genetic variation of Douglas-fir to guide seed transfer in southwest Oregon. Silvae Genet. 35: 85-96.

CAmpbell, R. K., R. M. Echols and R. W. StonecypheR (1986): Genetic variances and interactions in 9-year Douglas-fir grown at narrow spacings. Silvae Genet. 35: 24-32.

CotTerill, P. P. and J. W. JAMEs (1984): Number of offspring and plot sizes required for progeny testing. Silvae Genet. 33: 203-209.

FALCONER, D. S. (1981): Introduction to Quantative Genetics. Second Edition. Longman Group, Essex, United Kingdom.

Goodnight, J. H. and F. M. Speed (1978): Computing expected mean squares. SAS Institute Technical Report R-102. SAS Institute Inc.: Cary, North Carolina.

Husch, B., C. I. Miller and T. W. Bears (1972): Forest Mensuation. John Wiley and Sons, New York.

Johnson, G. R., R. A. SNiEzko and N. L. MANDEL (1997): Age trends in Douglas-fir genetic parameters and implications for optimum selection age. Silvae Genet. 46: $349-358$.
King, J. N., F. C. YeH, J. C. H. Heaman and B. P. DANCIK (1988a): Selection of wood density and diameter in controlled crosses of coastal Douglas-fir. Silvae Genet. 37: 152-157.

King, J. N., F. C. YeH and J. C. H. Heaman (1988b): Selection of growth and yield traits in controlled crosses of coastal Douglas-fir. Silvae Genet. 37: 158-164.

LAMBETH, C. C. (1980): Juvenile-mature correlations in Pinaceae and implications for early selection. For. Sci. 26: $571-580$.

Loo-Dinkins, J. A., C. C. Ying and E. A. HAMM (1991): Stem volume and wood relative density of a non-local Douglas-fir provenance in British Columbia. Silvae Genet. 40: 29-35.

Magnussen, S. and A. D. YanchuK (1988): Selection age and risk: Finding the compromise. Silvae Genet. 42: $25-40$.

Namkoong, G., R. A. Usanis and R. R. Silen (1972): Agerelated variation in genetic control of height growth in Douglas-fir. Theor. and Appl. Genet. 42: 151-159.

SAS Institute Inc. (1990): User's guide. Cary, North Carolina: SAS Institute Inc.

Stonecypher, R. W., R. F. Piesch, G. G. Helland, J. G. CHAPMAN and H. J. RENO (1996): Results from genetic tests of selected parents of Douglas-fir (Pseudotsuga menziesii [MIRB.] FrANCO) in an applied tree improvement program. Forest Sci. Monograph 32: 1-35.

SQUILlaCE, A. E. (1974): Average genetic correlations among offspring from open-pollinated forest trees. Silvae Genet. 23: 149-156.

TuRNer, H. N. and S. S. Y. Young (1969): Quantitative Genetics in Sheep Breeding. Macmillan, Australia.

\title{
Bud Removal Affects Shoot, Root, and Callus Development of Hardwood Populus Cuttings
}

\author{
By A. H. Wiese ${ }^{1)}$, J. A. Zalesny ${ }^{2)}$, D. M. Donner ${ }^{1)}$ and R. S. ZAlesny JR. ${ }^{1)}{ }^{*}$ )
}

(Received 23 $3^{\text {rd }}$ December 2005)

\begin{abstract}
The inadvertent removal and/or damage of buds during processing and planting of hardwood poplar (Populus spp.) cuttings are a concern because of their potential impact on shoot and root development during establishment. The objective of the current study was to test for differences in shoot dry mass, root dry mass, number of roots, length of the longest root, and callus dry mass among ten poplar clones subjected to three pre-planting

\footnotetext{
1) USDA Forest Service, North Central Research Station, Forestry Sciences Laboratory, 5985 Highway K, Rhinelander, WI 54501, U.S.A.

2) Iowa State University, Department of Natural Resource Ecology and Management, 339 Science II, Ames, IA 50011, U.S.A.

*) Corresponding author (research plant geneticist); Phone: (715) 362-1132; Fax: (715) 362-1166; E-mail: rzalesny@ @fs.fed.us.
}

bud removal intensities $(0 \%, 50 \%, 100 \%)$. The ten clones and their genomic groups were: DM115 (P. deltoides Bartr. ex Marsh x P. maximowiczii A. Henry); DN34, I45-51 (P. deltoides x $P$. nigra L.); NC13446, NC13563, NC13649, NC13685, NC13747 [(P. trichocarpa Torr. \& Gray $\times$ P. deltoides) $\times$ P. deltoides]; and NM2, NM6 ( $P$. nigra $\times P$. maximowiczii). Cuttings, $20 \mathrm{~cm}$ long, were processed from shoots collected January 2005 from stool beds established at Hugo Sauer Nursery in Rhinelander, Wisconsin, U.S.A. $\left(45.6^{\circ} \mathrm{N}, 89.4^{\circ} \mathrm{W}\right)$. We measured the traits from harvested cuttings after $14 \mathrm{~d}$ of growth. The treatment $x$ clone interaction governed shoot dry mass $(P<0.0001)$. In general, the top four clones (DM115, DN34, NM2, NM6) exhibited the best shoot dry mass with $0 \%$ and $50 \%$ of buds removed, while differences among treatments for the remaining clones were negligible. Clones differed for root dry mass 
$(P<0.0001)$, while the treatment and clone main effects governed number of roots $(P=0.0126, P<0.0001$, respectively) and length of the longest root $(P=0.0077$, $P<0.0001$, respectively). Cuttings subjected to the $0 \%$ treatment exhibited the greatest number of roots, while cuttings of the $0 \%$ and $50 \%$ treatment exhibited the greatest length of the longest root. The treatment $x$ clone interaction governed the presence of callus $(P=$ $0.0161)$, while clones differed for callus dry mass $(P<$ 0.0001). Bud removal did not affect root biomass but it did impact root initiation. Unlike shoot dry mass, the response to removing buds for all rooting traits was not clone-specific. From a practical standpoint, inadvertently damaging and/or removing $\leq 50 \%$ of the buds during processing and planting should not be a concern for establishment.

Key words: adventitious rooting, hybrid poplar, preplanting treatment, vegetative propagation, Populus deltoides, $P$. nigra, P. maximowiczii, $P$. trichocarpa.

\section{Introduction}

Short rotation intensive forestry systems have gained global credibility during the latter half of the $20^{\text {th }}$ century and beginning of the $21^{\text {st }}$ century because of the persistent need for fiber, wood products, and environmental services resulting from human population growth (HEILMAN, 1999; TOLBERT and WRIGHT, 1998; JOSLIN and Schoenholtz, 1997). The need for short rotation forestry in the North Central United States has become prevalent in past decades because of the loss of native forests to urbanization, the decrease in wood production from public forests, and the time required for native aspen [Populus tremuloides Michx. \{quaking aspen\}; Populus grandidentata Michx. \{bigtooth aspen\}] to reach merchantable size following intensive harvesting (GLADSTONE and LEDIG, 1990).

The use of species and hybrids within the genus Populus (hereafter referred to as poplars) have been developed, tested, and deployed in the North Central United States since the 1970's (ZALESNY et al., 2005b; RIEMENSCHNEIDER et al., 2001; RoBISON and RAFFA, 1996; FARMer et al., 1989; Ying and BAgley, 1976). Poplars have proven to be useful alternatives to the region's native aspen supply, which is projected to be inadequate to meet increased fiber demands within the next decade (PIVA, 2005). In addition, poplar is becoming a key woody crop for such uses as bioenergy, phytoremediation, agroforestry, and aesthetics (ZALESNY et al., 2005c; SCHULTZ et al., 2004; IsEBRANDS and KARNOSKY, 2001; HusAin et al., 1998). However, despite decades of testing, there are information gaps with respect to genotype $x$ environment interactions for aboveground and belowground traits (ZALESNY et al., 2005a; 2005b; RIEMENSCHNEIDER et al., 2001), levels of resistance/tolerance to diseases and insects (COYLE et al., 2005; 2003; TABOR et al., 2000), and the effect of preplanting treatments on the success of plantation establishment (DEsRocheRs and THOMAs, 2003; ZALESNY et al., 2003). Most preplanting treatments for poplars have focused attention on the following external factors: cutting size, planting date and methodology, environmental preconditioning, storage and/or soaking, chemical stimulation, soil tempera- ture, date of shoot collection, and shoot position along the parent shoot (ZALESNY and WiESE, 2006; FEgE, 1983). However, despite limited studies (SMITH and WAREING, 1974; 1972; EGGENS et al., 1972; FARMER, 1966floral buds), there is scarce information about the effects of bud removal on early shoot and root development of current poplar genotypes.

We believe information about the effects of bud removal on early production of dormant hardwood poplar cuttings is important because removal and/or damage of buds are inevitable during processing and planting. Consequently, regardless of the end-use of these short rotation crops, everyone establishing poplars as unrooted cuttings should be concerned with whether or not inadvertent removal and/or damage of buds during processing and planting are detrimental to shoot and root development of the cuttings during the initial stage of tree establishment directly following planting. To address this concern, the objective of the current study was to test for differences in shoot dry mass, root dry mass, number of roots, length of the longest root, and callus dry mass among ten poplar clones subjected to three pre-planting bud removal intensities $(0 \%, 50 \%$, $100 \%)$. Our initial hypotheses were two-fold. First, bud removal intensity would be inversely related to shoot, root, and callus development (i.e. cuttings of the control treatment would exhibit the greatest level of all traits). Second, the effects of bud removal would be clone-specific for all traits (i.e. clones would respond differently to the treatments). We believe this information is important because successful establishment is the most important requirement for success of all short rotation intensive culture systems.

\section{Materials and Methods \\ Clone selection}

Ten poplar (Populus spp.) clones were selected from four genomic groups during January 2005 based on their current utilization and growth potential in the North Central United States and their anticipated range of rooting abilities. The clones were: DM115 (P. deltoides Bartr. ex Marsh $\mathrm{x} P$. maximowiczii A. Henry); DN34, I45-51 ( $P$. deltoides $\times$ P. nigra L.); NC13446, NC13563, NC13649, NC13685, NC13747 [(P. trichocarpa Torr. \& Gray $\times \quad P$. deltoides $) \times P$. deltoides]; and NM2, NM6 (P. nigra $\times$ P. maximowiczii).

\section{Cutting preparation and treatment application}

Shoots were collected on January 11, 2005 from stool beds established at Hugo Sauer Nursery in Rhinelander, Wisconsin, U.S.A. $\left(45.6^{\circ} \mathrm{N}, 89.4^{\circ} \mathrm{W}\right)$. Hardwood cuttings, $20 \mathrm{~cm}$ long, were processed immediately following shoot collection, with cuts made to position at least one primary bud not more than $2.54 \mathrm{~cm}$ from the top of each cutting. Cuttings were sealed in polyethylene bags and stored at $5{ }^{\circ} \mathrm{C}$ for $28 \mathrm{~d}$. Before planting, treatments consisting of $0 \%, 50 \%$, and $100 \%$ bud removal were applied to the cuttings. The $0 \%$ treatment served as the experimental control. The $50 \%$ treatment consisted of removing the uppermost bud and then removing every other bud in a basipetal direction until half of the buds were removed. Bud removal consisted of using a razor blade 
and slicing the base of the bud at a plane perpendicular to the cutting so as not to damage cutting tissue or the axillary buds.

\section{Planting}

Cuttings were soaked in water to a height of $15 \mathrm{~cm}$ for $3 \mathrm{~d}$ at a daytime and nighttime temperature of $24^{\circ} \mathrm{C}$ and $20^{\circ} \mathrm{C}$, respectively, before planting in book planters containing equal parts of sand, peat, and vermiculite (v:v:v). Planting took place on February 8, 2005 in a greenhouse at the Forestry Sciences Laboratory in Rhinelander with a 16 -h photoperiod and air temperatures equal to those used for soaking. The cuttings were irrigated with overhead irrigation at a frequency of $15 \mathrm{~s}$ $\mathrm{h}^{-1} \mathrm{~d}^{-1}$, a watering schedule that provides good growing conditions.

\section{Data collection and analysis}

Shoot, root, callus, and cutting dry mass, number of roots, and length of the longest root were determined 14 $\mathrm{d}$ after planting. Trees were excavated and washed prior to dissection of shoots, roots, and callus. Following dissection, number of roots and length of the longest root were recorded, and individual plant components were bagged and dried at $70^{\circ} \mathrm{C}$ for $72 \mathrm{~h}$ for dry mass determination.

Shoot and root dry mass, number of roots, and length of the longest root data were subjected to analyses of variance according to $\mathrm{SAS}^{\circledR}$ (PROC GLM; SAS InstiTUTE, Inc., 2004) assuming a split-plot design arranged in randomized complete blocks, with six blocks, three treatments $(0 \%, 50 \%, 100 \%$ bud removal), and ten clones. Blocks were considered random in the analysis, while treatments were fixed whole plots and clones were fixed sub plots. Clones were arranged in randomized complete blocks in order to minimize effects of any potential environmental gradients in the greenhouse, and clones were treated as fixed in the analysis in order to analyze means rather than variances. The significance of the interaction between block and clone from the original all-effects model was tested to evaluate potential pooling with the residual error term (the three-way interaction between block, treatment, and clone) to increase precision of F-tests, assuming a probability level for pooling of $P \geq 0.25$ (ZALESNY et al., 2005b). Probability levels associated with the interaction between block and clone for shoot dry mass, root dry mass, number of roots, and length of the longest root were $P=0.4040, P=0.9607, P=0.1305$, and $P=0.0385$, respectively. Therefore, the block $\mathrm{x}$ clone interaction was pooled with the residual error term for shoot dry mass and root dry mass, but not for the other two rooting traits. Thus, the following linear additive model was used for shoot dry mass and root dry mass:

$$
\mathrm{Y}_{\mathrm{ijk}}=\mu+\mathrm{B}_{\mathrm{i}}+\mathrm{T}_{\mathrm{j}}+\mathrm{BT}_{\mathrm{ij}}+\mathrm{C}_{\mathrm{k}}+\mathrm{TC}_{\mathrm{jk}}+\text { Pooled Error }
$$

where: $\mathrm{Y}_{\mathrm{ijk}}=$ response variable to be analyzed, $\mu=$ overall mean, $B_{i}=$ main effect of $i^{\text {th }}$ block, $T_{j}=$ main effect of $\mathrm{j}^{\text {th }}$ treatment, $\mathrm{BT}_{\mathrm{ij}}=$ effect of interaction between $\mathrm{i}^{\text {th }}$ block and $\mathrm{j}^{\text {th }}$ treatment, $\mathrm{C}_{\mathrm{k}}=$ main effect of $\mathrm{k}^{\text {th }}$ clone, $\mathrm{TC}_{\mathrm{jk}}=$ effect of interaction between $\mathrm{j}^{\text {th }}$ treatment and $\mathrm{k}^{\text {th }}$ clone, and pooled error = error term resulting from pooling of $\mathrm{BC}_{\mathrm{ik}}$ and $\mathrm{BTC}_{\mathrm{ijk}}$ terms, defined as: effect of inter- action among $\mathrm{i}^{\text {th }}$ block and $\mathrm{k}^{\text {th }}$ clone, and effect of interaction between $\mathrm{i}^{\text {th }}$ block, $\mathrm{j}^{\text {th }}$ treatment, and $\mathrm{k}^{\text {th }}$ clone, respectively.

In contrast, the following linear additive model was used for number of roots and length of the longest root:

$$
\mathrm{Y}_{\mathrm{ijk}}=\mu+\mathrm{B}_{\mathrm{i}}+\mathrm{T}_{\mathrm{j}}+\mathrm{BT}_{\mathrm{ij}}+\mathrm{C}_{\mathrm{k}}+\mathrm{BC}_{\mathrm{ik}}+\mathrm{TC}_{\mathrm{jk}}+\mathrm{BTC}_{\mathrm{ijk}}
$$

where variables were as defined above.

Analyses of covariance were conducted to test for the effect of cutting size on all traits because of broad variation in cutting dry mass at $14 \mathrm{~d}$ after planting (1.23 to $7.55 \mathrm{~g})$. Cutting dry mass was a significant covariate for shoot dry mass $(P<0.0001)$, root dry mass $(P=0.0042)$, and length of the longest root $(P=0.0031)$; however, cutting dry mass did not have an effect on number of roots $(P=0.7146)$. Therefore, all means except for number of roots were adjusted for the variation in cutting dry mass. Fisher's protected least significant difference (LSD) was used to compare adjusted and unadjusted means (CARMER and WALKER, 1985; 1982).

The data for callus dry mass were left-skewed with $29 \%$ of the cuttings failing to initiate callus formation. Therefore, non-parametric tests were used to evaluate callus formation across treatments and clones. First, a Chi-square $\left(\chi^{2}\right)$ test from frequency counts was used to analyze differences for the presence of callus (CODY and SMITH, 1997). However, these data must be interpreted with caution because most expected values in the $\chi^{2}$ table were estimated with a number of observations less than five. Second, the Kruskal-Wallis Test (an ANOVA on ranks) was used to test for differences in callus dry mass using the all-effects split-plot model described above. A Bonferroni adjustment $\left(\alpha^{\prime}\right)$ of $[\alpha /(k\{k-1\} / 2)]=$ 0.0011 ( $\alpha=0.05$ and $\mathrm{k}=10$ ) was used to limit the experiment-wise error rate to $\alpha \leq 0.05$. Significant effects were differentiated according to Fisher's protected LSD using $\alpha^{\prime}=0.0011$ in lieu of $\alpha=0.05$.

\section{Results}

Treatment and clone main effects were significant for shoot dry mass $(P=0.0004, P<0.0001$, respectively), but the treatment $x$ clone interaction governed this trait $(P<0.0001)$. There was broad variation among clonal responses to treatments, with a general trend for the top four clones (DM115, DN34, NM2, NM6) of cuttings subjected to $0 \%$ and $50 \%$ of buds removed exhibiting greater shoot dry mass than those with $100 \%$ of buds removed (Fig. 1). Cuttings of the $0 \%$ and $50 \%$ treatments were not different for clones DN34 and NM2, while shoot dry mass from cuttings of the $0 \%$ treatment were superior to those of the $50 \%$ treatment for clones DM115 and NM6. Differences among treatments for the remaining six clones were negligible. Overall, shoot dry mass across treatments and clones ranged from $0.00 \pm 0.00$ to $160.27 \pm 15.06 \mathrm{mg}$, with a mean of $45.05 \pm 9.01 \mathrm{mg}$.

The main effect of treatment and the treatment $x$ clone interaction were negligible for root dry mass $(P=$ $0.0857, P=0.2165$, respectively), but clones differed for this trait $(P<0.0001)$. There was extensive genotypic variation among clones belonging to the backcross 
genomic group $[(P$. trichocarpa $\times P$. deltoides $) \times P$. deltoides; the NCxxx clones] (Fig. 2), which was expected given the potential variation in allele distribution during backcross breeding. Clone I45-51 exhibited the least root dry mass that was not different from any backcross clone except NC13446. Overall, root dry mass across clones ranged from $7.12 \pm 11.56$ to $137.78 \pm 12.49 \mathrm{mg}$, with a mean of $58.59 \pm 14.44 \mathrm{mg}$.

Treatment and clone main effects were significant for number of roots $(P=0.0126, P<0.0001$, respectively), while the treatment $x$ clone interaction was negligible for this trait $(P=0.1903)$. Cuttings subjected to the $0 \%$ treatment exhibited the greatest number of roots that was significantly greater than the $50 \%$ and $100 \%$ treatments $(7.62 \pm 0.92,5.43 \pm 0.67,4.82 \pm 0.74$, respectively), which were not different from one another $(\alpha=0.05$, $\mathrm{n}=60, \mathrm{LSD}=1.75$ ). The genotypic response for number of roots was similar to that of root dry mass with respect to clonal ranks and variation among the backcross clones; however, other genotypic differences varied for each trait (Fig. 2). Overall, number of roots across clones ranged from $0.3 \pm 0.2$ to $12.7 \pm 0.6$, with a mean of $6.0 \pm$ 1.5.

Similarly, treatment and clone main effects were significant for length of the longest root $(P=0.0077, P<$ 0.0001 , respectively), while the treatment $x$ clone interaction was negligible for this trait $(P=0.7577)$. Cuttings subjected to the $0 \%$ and $50 \%$ treatment were not different from one another and exhibited greater length of the longest root than those of the $100 \%$ bud removal treatment $(5.95 \pm 0.34 \mathrm{~cm}, 5.56 \pm 0.34 \mathrm{~cm}, 4.57 \pm 0.34 \mathrm{~cm}$, respectively; $\alpha=0.05, \mathrm{n}=60, \mathrm{LSD}=0.80$ ). Clones segregated into four response groups for length of the longest root (Fig. 2). Clone NM6 was superior to all other clones, while clones DM115 and NM2 exhibited the second best length. All other clones responded similarly and less

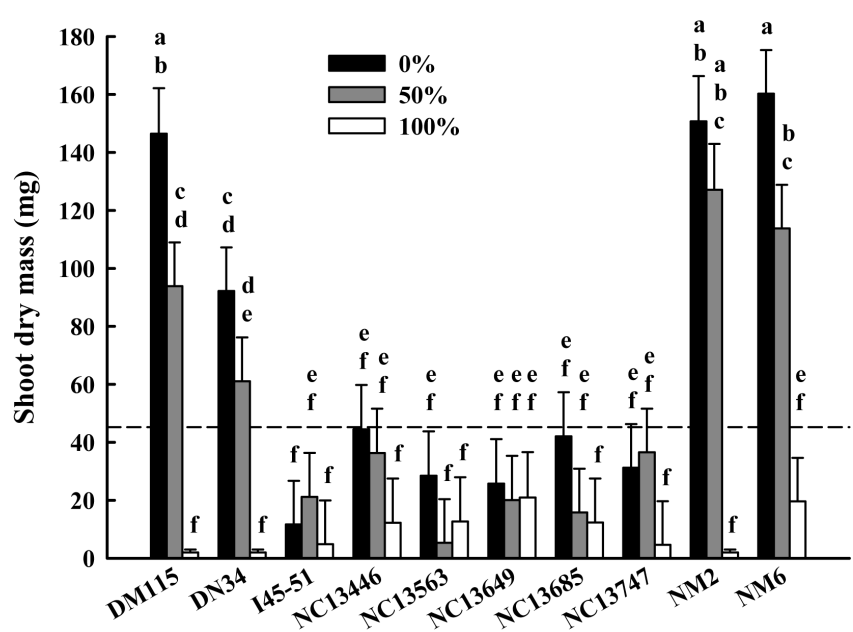

Clone

Figure 1. - Shoot dry mass after $14 \mathrm{~d}$ of growth for each combination of treatment $(0 \%, 50 \%$, and $100 \%$ of buds removed) and clone in an experiment testing the effects of bud removal on above- and below-ground growth of dormant hardwood cuttings of Populus. Each bar represents the mean adjusted for cutting dry mass with one standard error. Bars with the same letter are not different according to Fisher's protected least significant difference (LSD) $(\alpha=0.05 ; \mathrm{n}=6$; LSD $=45.66)$. The dashed line represents the overall mean.
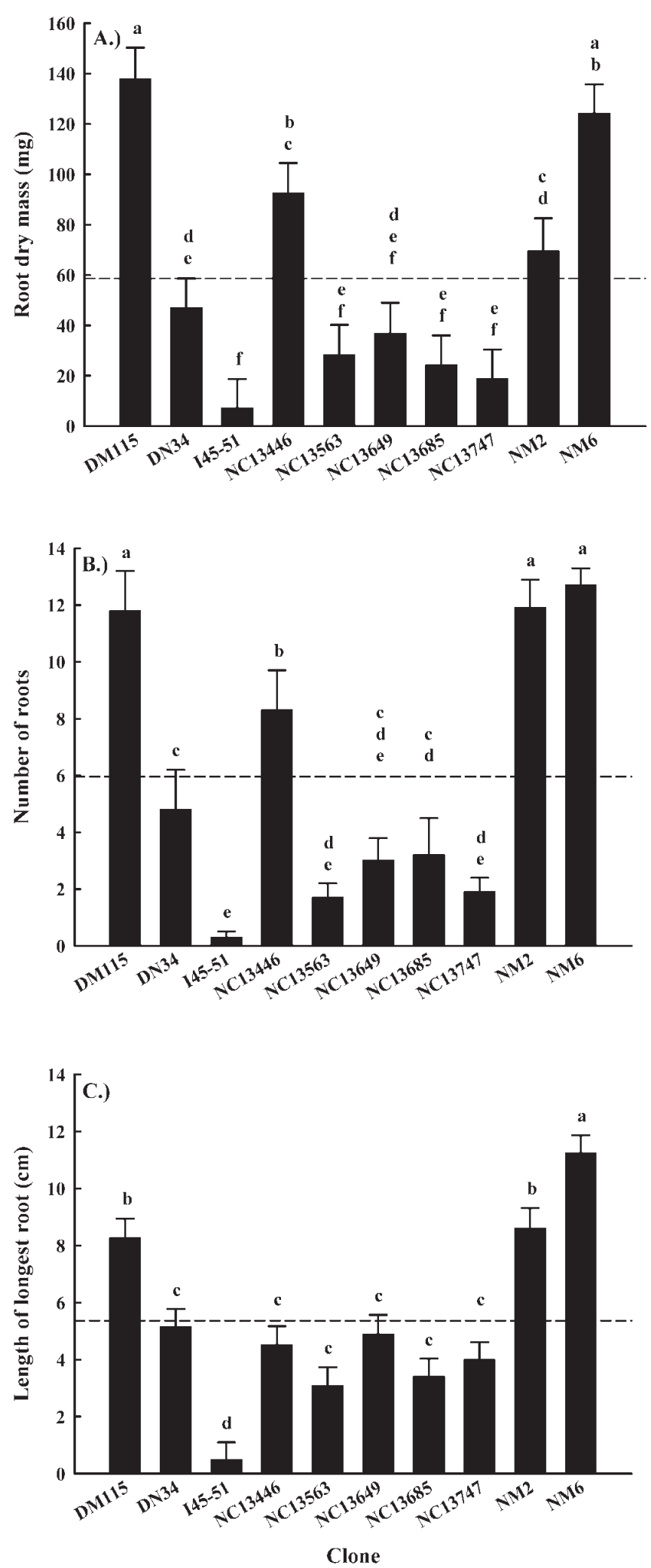

Figure 2. - Root dry mass (A.), number of roots (B.), and length of the longest root (C.) after $14 \mathrm{~d}$ of growth across treatments for each clone in an experiment testing the effects of bud removal on above- and below-ground growth of dormant hardwood cuttings of Populus. Each bar represents the mean adjusted (A. and C.) and unadjusted (B.) for cutting dry mass, with one standard error. Bars with the same letter are not different according to Fisher's protected least significant difference (LSD) $\left(\alpha=0.05 ; \mathrm{n}=18 ; \mathrm{LSD}_{\text {root dry mass }}=33.18\right.$; $\left.\mathrm{LSD}_{\text {number of roots }}=2.75 ; \mathrm{LSD}_{\text {length of longest root }}=2.30\right)$. The dashed line represents the overall mean for each trait. 
Table 1. - Callus dry mass of ten clones in an experiment testing the effects of bud removal on above- and below-ground growth of dormant hardwood cuttings of Populus. Clones were differentiated using the Kruskal-Wallis Test (an ANOVA on ranks), with a Bonferroni adjustment $\left(\alpha^{\prime}\right)$ of $[\alpha /(\mathrm{k}\{\mathrm{k}-1\} / 2)]=0.0011(\alpha=0.05$ and $\mathrm{k}=10)$ to limit the experiment-wise error rate to $\alpha \leq 0.05$. Clones with the same letter are not different according to Fisher's protected least significant difference (LSD) $\left(\alpha^{\prime}=0.0011 ; n=18\right.$; $\mathrm{LSD}=44.09$ ).

Callus dry mass (mg)

\begin{tabular}{lrrrrr} 
Clone & Mean rank & Minimum & Mean $( \pm$ standard error $)$ & Maximum \\
\hline NM2 & 32.81 & a & 2.2 & $40.87 \pm 5.38$ & 89.2 \\
NM6 & 49.03 & a & 13.8 & $26.34 \pm 2.14$ & 47.5 \\
DM115 & 52.97 & a b & 0.0 & $28.41 \pm 3.85$ & 59.3 \\
NC13446 & 74.11 & a b c & 0.0 & $19.74 \pm 3.81$ & 49.3 \\
DN34 & 95.75 & b c d & 0.0 & $12.59 \pm 2.62$ & 35.8 \\
NC13649 & 109.19 & c d & 0.0 & $10.86 \pm 4.08$ & 65.0 \\
I45-51 & 115.25 & c d & 0.0 & $7.52 \pm 3.14$ & 52.0 \\
NC13747 & 117.78 & c d & 0.0 & $5.85 \pm 1.97$ & 30.1 \\
NC13563 & 126.50 & d & 0.0 & $5.39 \pm 2.10$ & 28.8 \\
NC13685 & 131.61 & d & 0.0 & $3.51 \pm 1.63$ & 22.4 \\
\hline
\end{tabular}

favorably than those in the aforementioned response groups, with the exception of clone I45-51 that exhibited the shortest roots. Overall, length of the longest root across clones ranged from $0.5 \pm 0.5$ to $11.2 \pm 0.6 \mathrm{~cm}$, with a mean of $5.4 \pm 1.0 \mathrm{~cm}$.

The main effect of treatment was negligible for the presence of callus $(P=0.8986)$, while clones differed for this trait $(P<0.0001)$. However, the treatment $\mathrm{x}$ clone interaction governed the presence of callus $(P=0.0161)$. Nevertheless, the frequency of cuttings developing or failing to develop callus was stable ( \pm one cutting) across treatments for all clones except clone I45-51. In this case, five cuttings of the $100 \%$ bud removal treatment developed callus and one failed to develop callus, compared to three cuttings developing versus three cuttings failing to develop callus for the $0 \%$ and $50 \%$ treatments. Moreover, according to an ANOVA on ranks, the main effect of treatment and the treatment $x$ clone interaction were negligible for callus dry mass rank $(P=0.2975$, $P=0.2975$, respectively), but clones differed for this variable $(P<0.0001)$. Similar to root dry mass and number of roots, there was broad variation among backcross clones for callus dry mass (Table 1). Overall, callus dry mass ranged from 0.00 to $89.20 \mathrm{mg}$, with a mean of $16.11 \pm 3.91 \mathrm{mg}$.

\section{Discussion}

In general, removing less than or equal to $50 \%$ of the buds from the poplar cuttings in the current study was not detrimental to cutting establishment. However, our first hypothesis was upheld. That is, the intensity of bud removal was inversely related to shoot, root, and callus development. In general, cuttings subjected to $0 \%$ and $50 \%$ bud removal exhibited better growth than those with complete bud removal. Thus, we speculate a threshold intensity of bud removal exists between $50 \%$ and $100 \%$, above which substantial impacts to shoot, root, and callus development begin. Unfortunately, the methodology of the current study did not allow testing for the identification of this intensity of substantial impact. However, future studies can be designed adequately to address this issue. Moreover, our second hypothesis was not upheld for all traits. That is, the interaction between treatment and clone was negligible for all rooting traits and callus dry mass, despite varying clonal responses to bud removal intensities for shoot dry mass and the presence of callus. Once again, further studies are needed to address the issue of clone-specificity towards different intensities of bud removal. Testing a greater number of clones that represent more genomic groups also is needed. 
The interaction between treatment and clone for shoot dry mass is intuitive, given reported data illustrating clonal differences among these genomic groups for aboveground traits (ZALESNY et al., 2005b; 2004; RIEMENSCHNEIDER et al., 2001) and that removal of buds should have an impact on the capability of the newly developing cutting to produce a shoot. Although poplars have two axillary buds at the base of each primary bud (LARSON and Pizzolato, 1977), $14 \mathrm{~d}$ may be too short of a time period for axillary bud initiation and subsequent shoot growth for some genotypes. For example, despite extensive genotypic variability within our backcross population, there were no differences in the response of the backcross clones to treatments. This could be the result of relatively greater axillary bud initiation among the backcross clones compared with those of other genomic groups. There is one exception. Clones DN34 and I45-51 belong to the same genomic group, yet clone I45-51 appeared to exhibit a similar level of axillary bud initiation as the backcross clones, whereby clone DN34 was not able to respond as quickly when all of the buds were removed. Thus, an important practical implication for shoot dry mass is that clones such as DM115, DN34, NM2, and NM6 were more sensitive to complete bud removal, where clones such as I45-51 and the backcross clones were robust to $100 \%$ bud removal.

The lack of treatment effects for root dry mass and presence of such effects for number of roots and length of the longest root also are intuitive, given that root dry mass is proportional to storage capacity and the other traits are indicative of meristematic activity and subsequent growth. Researchers have reported root development (i.e. biomass) and root initiation (i.e. number of roots) are regulated by different mechanisms (FRIEND et al., 1994; HAISsig and DAVIS, 1994; Lux, 1978). For example, DesRochers and Thomas (2003) reported negligible differences for root mass between $5 \mathrm{~cm}$ cuttings with a single bud and $10 \mathrm{~cm}$ cuttings with multiple buds, despite differences between the cutting groups for root initiation (represented by percent rooting). Consequently, they speculated different mechanisms were responsible for root development and root initiation (DesRochers and Thomas, 2003). Traditionally, root dry mass has been the most common parameter for rooting studies because of its ease of estimation before the advent of modern equipment (BöHM, 1979). However, we believe the lack of treatment effects for root dry mass most likely was the result of cuttings being grown for $14 \mathrm{~d}$, during which meristematic activity, root initiation, and subsequent growth in length were more prevalent than storage functions. Nevertheless, the treatment response for number of roots of our cuttings corroborated the results of previous studies (SMITH and WAREING, 1974). For example, EGGENs et al. (1972) reported single root initiation from cuttings without buds and numerous roots from cuttings with buds. SMITH and WAREING (1972) reported 1.9 times the number of roots from cuttings with buds versus debudded cuttings, both grown for $21 \mathrm{~d}$ at $20^{\circ} \mathrm{C}$. In the current study, cuttings of the $0 \%$ treatment exhibited greater than 1.5 times the number of roots as those of the $100 \%$ treatment. In addition to the lack or presence of treatment effects, clonal differences for all rooting traits corroborate findings of previous studies (ZALESNY et al., 2005a; 2005b; 2003; RIEMENSCHNEIDER and BAUER, 1997; FARMER et al., 1989; YING and BAGLEY, 1977; WILCOX and FARMER, 1968).

The interaction between treatment and clone for the presence of callus must be interpreted with caution, given the small sample sizes used for the expected values in the $\chi^{2}$ test. The frequency counts were consistent across treatments for all genotypes other than clone I4551. However, differences among clones existed, regardless of treatment. Similarly, there was broad variation in callus dry mass across clones, according to the ANOVA on ranks. Although treatments were negligible for callus development, the practical implication of these results was that callus production was under strong genetic control and, therefore, should be responsive to selection. Furthermore, selection of clones with great levels of callus dry mass offers a means of potentially increasing the capability of successful cutting establishment, because callus root development is one of two rooting ontogenies present in the genus Populus (LuxoVA and LuX, 1981a; 1981b).

\section{Conclusion}

Early establishment of poplar cuttings depends upon successful rooting and subsequent shoot growth. External factors affecting cutting production and establishment include but are not limited to: insects, diseases, herbivores, environmental damage, and mechanical activities. Regardless of the extent of impact from such factors, it is important to consider what effects the damage and/or removal of buds has on early shoot and root development of hardwood poplar cuttings. Results from the current study must be interpreted considering that the cuttings were grown in a greenhouse with minimal stress, in contrast to a field setting where the aforementioned external factors are prevalent. Nevertheless, the two primary lessons from this study are important for short rotation intensive forestry. First, bud removal did not affect root biomass but greater intensities did impact root initiation. Second, unlike shoot dry mass, the response to removing buds for all rooting traits was not clone-specific. Overall, from a practical standpoint, inadvertently damaging and/or removing some buds during processing and planting should not be a concern for establishment. However, if greater than $50 \%$ of the buds on any individual cutting are damaged and/or removed, that cutting should not be used, regardless of genotype.

\section{Acknowledgements}

We are grateful to the following people for helpful comments on earlier versions of this manuscript: EDMUND Bauer, Daniel Baumann, Robert Bridges, David Buckley, Craig Halla, Dan Langseth, Neil Nelson and Don RIEMENSCHNEIDER.

\section{References}

Bӧнм, W. (1979): Methods of Studying Root Systems. Springer-Verlag, Berlin-Heidelberg. 
CARMer, S. G. and W. M. WALker (1985): Pairwise multiple comparisons of treatment means in agronomic research. J. Agron. Educ. 14: 19-26.

CARmer, S. G. and W. M. WAlker (1982): Baby Bear's dilemma: a statistical tale. Agron. J. 74: 122-124.

Cody, R. P. and J. K. Smith (1997): Applied Statistics and the $\mathrm{SAS}^{\circledR}$ Programming Language $\left(4^{\text {th }}\right.$ ed). Prentice Hall, Upper Saddle River, New Jersey.

Coyle, D. R., T. E. Nebeker, E. R. Hart and W. J. MatTSON, JR. (2005): Biology and management of insect pests in North American intensively-managed hardwood forest systems. Ann. Rev. Entomol. 50: 1-29.

Coyle, D. R., J. D. McMillin, R. B. Hall and E. R. HaRT (2003): Effects of cottonwood leaf beetle (Coleoptera: Chrysomelidae) larval defoliation, clone, and season on Populus foliar phagostimulants. Environ. Entomol. 32: 452-462.

DesRochers, A. and B. R. Thomas (2003): A comparison of pre-planting treatments on hardwood cuttings of four hybrid poplar clones. New For. 26: 17-32.

EgGens, J. L., E. C. Lougheed and R. J. Hilton (1972): Rooting of hardwood cuttings of Bolleana poplar. Can. J. Plant Sci. 52: 599-604.

FARMER, R. E., JR. (1966): Rooting dormant cuttings of mature cottonwood. J. For. 64: 196-197.

FARMER, R. E., JR., M. Freitag and K. GARLick (1989): Genetic variance and "C" effects in balsam poplar rooting. Silvae Genet. 38: 62-65.

FEGE, A. S. (1983): The practice and physiological basis of collecting, storing, and planting Populus hardwood cuttings, pp. 1-11. In: USDA For. Serv. Gen. Tech. Rep. NC-GTR-91.

Friend, A. L., M. D. Coleman and J. G. Isebrands (1994): Carbon allocation to root and shoot systems of woody plants, pp. 245-273. In: T. D. DAVIS and B. E. HAISSIG (eds). Biology of adventitious root formation. Plenum Press, New York.

Gladstone, W. T. and F. T. Ledig (1990): Reducing pressure on natural forests through high-yield forestry. For. Ecol. Mgt. 35: 69-78.

HAissig, B. E. and T. D. DAVIS (1994): A historical evaluation of adventitious rooting research to 1993, pp. 275-331. In: T. D. DAvis and B. E. HAIssig (eds). Biology of adventitious root formation. Plenum Press, New York.

Heilman, P. E. (1999): Planted forests: poplars. New For. 17: 89-93.

Husain, S. A., D. W. Rose and S. O. ARChibald (1998): Identifying agricultural sites for biomass energy production in Minnesota. Biomass Bioenergy 15: 423-435.

IsEBRANDS, J. G. and D. F. KARNOSKY (2001): Environmental benefits of poplar culture, pp. 207-218. In: D. I. Dickmann, J. G. Isebrands, J. E. Eckenwalder and J. RICHARDSON (eds). Poplar Culture in North America. NRC Research Press, National Research Council of Canada, Ottawa, ON K1A 0R6, Canada.

Joslin, J. D. and S. H. SchoenholTz (1997): Measuring the environmental effects of converting cropland to short-rotation woody crops: a research approach. Biomass Bioenergy 13: 301-311.

Larson, P. R. and T. D. Pizzolato (1977): Axillary bud development in Populus deltoides. I. Origin and early ontogeny. Amer. J. Bot. 64: 835-848.

Lux, A. (1978): Influence of the time factor on the rhizogenesis of poplar stem cuttings (hybrid I-214). Biologia (Bratislava) 33: 11-16.
Luxova, M. and A. Lux (1981a): The course of root differentiation from root primordia in poplar stems. Biol. Plant. 23: 401-405.

Luxova, M. and A. Lux (1981b): Latent root primordia in poplar stems. Biol. Plant. 23: 285-290.

PIVA, R. J. (2005): Pulpwood production in the North-Central Region, 2002. USDA For. Serv., NC Res. Stat. Resour. Bull. NC-239.

Riemenschneider, D. E. and E. O. BAuer (1997): Quantitative genetic analysis of adventitious root forming ability in Populus trichocarpa (TORR ET. GRAY), pp. 193-201. In: A. Altman and Y. WAisel (eds). Biology of Root Formation and Development. Plenum Press, New York.

Riemenschneider, D. E., W. E. Berguson, D. I. Dickmann, R. B. Hall, J. G. Isebrands, C. A. Mohn, G. R. Stanosz and G. A. TUSKAN (2001): Poplar breeding and testing strategies in the north-central U.S.: demonstration of potential yield and consideration of future research needs. For. Chron. 77: 245-253.

RoBisON, D. J. and K. F. RAFFA (1996): Importance of cutting diameter and method of production on early growth of hybrid poplar. Tree Plant. Not. 47: 76-80.

SAS InstituTE, Inc. (2004): SAS/STAT ${ }^{\circledR} 9.1$ User's Guide. Cary, NC.

Schultz, R. C., T. M. Isenhart, W. W. Simpkins and J. P. Colletti (2004): Riparian forest buffers in agroecosystems - lessons learned from the Bear Creek Watershed, central Iowa, USA. Agroforestry 61: 35-50.

SMith, N. G. and P. F. WAREING (1974): The distribution of latent root primordia in stems of Populus $\underline{x}$ robusta, and factors affecting the emergence of preformed roots from cuttings. Forestry 45: 197-209.

SMITH, N. G. and P. F. WAREING (1972): Rooting of hardwood cuttings in relation to bud dormancy and the auxin content of the excised stems. New Phytol. 71: $63-80$.

Tabor, G. M., T. L. Kubisiak, N. B. Klopfenstein, R. B. HALL and H. S. MCNABB, JR. (2000): Bulked segregant analysis identifies molecular markers linked to Melampsora medusae resistance in Populus deltoides. Phytopathology 90: 1039-1042.

TOLBERT, V. R. and L. L. WRIGHT (1998): Environmental enhancement of U.S. biomass crop technologies: research results to date. Biomass Bioenergy 15: 93-100.

Wilcox, J. R. and R. E. FARMER, JR. (1968): Heritability and $\mathrm{C}$ effects in early root growth of eastern cottonwood cuttings. Heredity 23: 239-245.

YING, C. C. and W. T. BAGLEY (1977): Variation in rooting capability of Populus deltoides. Silvae Genet. 26: 204-207.

YING, C. C. and W. T. BAGLEY (1976): Genetic variation of eastern cottonwood in an eastern Nebraska provenance study. Silvae Genet. 25: 67-73.

Zalesny, R. S., JR. and A. H. Wiese (2006): Date of shoot collection, genotype, and original shoot position affect early rooting of dormant hardwood cuttings of Populus. Silvae Genet. (In press).

Zalesny, R. S., JR., R. B. Hall, E. O. Bauer and D. E. RIEMENSCHNEIDER (2005a): Soil temperature and precipitation affect the rooting ability of dormant hardwood cuttings of Populus. Silvae Genet. 54: 47-58.

Zalesny, R. S., JR., D. E. RIEMENSChNeider and R. B. HALL (2005b): Early rooting of dormant hardwood cuttings of Populus: analysis of quantitative genetics and genotype $x$ environment interactions. Can. J. For. Res. 35: 918-929. 
Zalesny, R. S., JR., E. O. Bauer, R. B. Hall, J. A Zalesny, J. Kunzman, C. J. Rog and D. E. RiemenSCHNEIDER (2005c): Clonal variation in survival and growth of hybrid poplar and willow in an in situ trial on soils heavily contaminated with petroleum hydrocarbons. Intl. J. Phytoremed. 7: 177-197.

Zalesny, R. S., JR., E. O. BAuer and D. E. RiemenSCHNEIDER (2004): Use of belowground growing degree days to predict rooting of dormant hardwood cuttings of Populus. Silvae Genet. 53: 154-160.

Zalesny, R. S., JR., R. B. Hall, E. O. Bauer and D. E. RIEMENSCHNEIDER (2003): Shoot position affects root initiation and growth of dormant unrooted cuttings of Populus. Silvae Genet. 52: 273-279.

\section{Book Review}

Saatgutbehandlung bei Nadelgehölzen. Von STEFAN SEIFERT. 2005. Diplomarbeit. 155 Seiten mit Farb-Fotos und Tabellen. Ringbindung. 27,50 EUR (Bezug: Versuchs- und Beratungsring Baumschulen SchleswigHolstein e.V., Bismarckstrasse 49, 25421 Pinneberg, E-Mail: info@VuB-Baumschulberatung.de).

An der Fachhochschule Osnabrück ist die über den Versuchs- und Beratungsring Baumschulen SchleswigHolstein $(\mathrm{VuB}) \mathrm{zu}$ beziehende Diplomarbeit entstanden. In der Einleitung erfährt der Leser, dass die vorliegende Arbeit die Ergänzung einer an der Universität Hannover erstellten Diplomarbeit zur Saatgutbehandlung von Laubgehölzen ist: Leider fehlen hierzu die bibliographischen Angaben. Im Folgenden werden die Mechanismen der Keimhemmung und Maßnahmen zu ihrer Überwindung erläutert; außerdem wird kurz auf Ernte und Herbstaussaat eingegangen. Die Ergebnisse der Arbeit beruhen auf einer Umfrage unter 21 norddeutschen Baumschulen, die Forstpflanzen, Jungpflanzen und/ oder Unterlagen von Nadelgehölzen produzieren. Das Kernstück der Diplomarbeit stellen die mehr als 100 Seiten umfassenden Ergebnisse dar, die in drei Teile gegliedert sind: Im ersten Teil werden die Betriebe charakterisiert sowie die Angaben zur Saatgutbeschaffung und Lagerung analysiert. Die Auswertung der Methoden, wie in den 21 befragten Betrieben das Saatgut vorbehandelt wird, und Angaben zu den technischen Einrichtungen der Baumschulen folgen im zweiten Teil. Im dritten und umfassendsten Teil beschreibt der Autor die Durchführung der Saatgutbehandlung von insgesamt 23 Arten: 6 Abies-, 5 Pinus-, 4 Picea- und 2 Larix-Arten sowie je eine Chamaecyparis-, Cedrus-, PseudotsugaTaxus-, Thuja- und Tsuga-Art. Dabei wird für jede Art nach gleichem Muster zunächst die Literatur zur Vorbehandlung ausgewertet; es folgen die in den Umfragebetrieben angewandten Vorbehandlungsmethoden. An- schließend werden die Methoden der Betriebe denen aus der Literatur gegenübergestellt. Für die Gegenüberstellung hat der Autor die Ergebnisse graphisch aufgearbeitet und die Diagramme in 2 Abbildungen pro Baumart zusammengestellt. Die eine Abbildung enthält allgemeine Angaben (Anzahl Samen/kg, Auflaufergebnisse, erzielbare Pflanzenanzahl $/ \mathrm{kg}$ ) aus der Literatur sowie die Vorbehandlungsmethoden der einzelnen Umfragebetriebe und aus der Literatur. In der anderen Abbildung sind für jeden der befragten Baumschulbetriebe Aussaatzeitpunkt und Pflanzenanzahl/kg Saatgut sowie zusammengefasst allgemeine Umfrageergebnisse (Mittel, Minimum und Maximum der Saatgutausbeute und der Auflaufdichte) aufgelistet. Im letzten Kapitel werden die für die meisten Gehölze oft unterschiedlichen Literaturangaben sowie die davon abweichenden Praxiserfahrungen diskutiert und Verbesserungsmöglichkeiten bei der Saatgutvorbehandlung abgeleitet. Das Literaturverzeichnis beinhaltet auf 10 Seiten die relevante nationale und internationale Literatur. Der Rezensent vermisst jedoch die Erfahrungen der Kollegen aus der Schweiz (BURKART, 2000). In einer wissenschaftlichen Arbeit sollte die fälschliche Verwendung des Begriffs Gewicht (korrekt wäre Masse) vermieden werden.

Trotz der kleinen Mängel ist die Diplomarbeit eine gelungene Zusammenstellung, die die Variation der Behandlungsmethoden aufzeigt und den Baumschulbetrieben Hinweise zur Optimierung gibt. Der Fachhochschule, dem VuB und der LWK Schleswig-Holstein ist zu danken, dass sie diese Diplomarbeit der Öffentlichkeit zugänglich machen. Die Ringbindung und die gewählte Papierqualität sind äußerst praxisfreundlich. Title: "Conifer seed treatment".

M. LIESEBACH (Waldsieversdorf)

Herausgeberin: Bundesforschungsanstalt für Forst- und Holzwirtschaft: Schriftleitung: Institut für Forstgenetik und Forstpflanzenzüchtung, Siekerlandstrasse 2, D-22927 Grosshansdorf - Verlag: J. D. Sauerländer's Verlag, Finkenhofstrasse 21, D-60322 Frankfurt a. M. Anzeigenverwaltung: J. D. Sauerländer's Verlag, Frankfurt am Main.

Satz und Druck: ADN Offsetdruck, Battenberg — Printed in Germany. 